\title{
Uticaj razvoja scienciometrije na izgled i funkcionisanje sistema nauke u svijetu i pojedinim državama*
}

\author{
Enver Zerem ${ }^{* *}$ \\ Suad Kunosic ${ }^{* * * *}$
}

Sažetak: Društveni značaj i kvalitet naučnog istraživanja u velikoj mjeri ovise o korisnosti rezultata istraživanja za društvenu i naučnu zajednicu. Nedostatak sredstava i želja da se sredstva dodijele visokokvalitetnim istraživanjima čine sve značajnijim procjenu kvaliteta istraživanja i valorizaciju znanja. Međutim, vrlo je teško primijeniti kriterije koji mogu objektivno procijeniti naučna istraživanja, pružajući precizne kvalitativne i kvantitativne podatke na kojima bi agencije za finansiranje mogle temeljiti svoje odluke. Proizvod naučnog istraživanja uglavnom su informacije objavljene u naučnim časopisima. One su temelj širenja znanja i osnovni kriterij za akademsku i naučnu evaluaciju, regrutovanje sredstava za naučna istraživanja i napredovanje u karijeri. Pored evaluacije naučnih publikacija, postoji širok spektar drugih aktivnosti koji odražavaju naučni kredibilitet znanstvenika, kao što su: broj i kvalitet grantova za naučnoistraživačke projekte, liderstvo u nacionalnim ili međunarodnim akademskim društvima, članstvo u redakcijama uglednih časopisa, mentorstva u doktorskim disertacijama i slično.

Mada su te aktivnosti važne i daju kredibilitet znanstveniku, relevantni scientimetrijski sistemi pokrivaju samo publikacije, izostavljajući druge kriterije od naučne važnosti, u ocjenjivanju prilikom akademskog napredovanja znanstvenika, kao i konkursima za dobijanje grantova za finansijsku potporu naučnim istraživanjima. Razlog tome je činjenica da su ove aktivnosti, bez obzira na važnost, vrlo heterogene, sa specifičnim karakteristikama i zahtijevaju veoma raznolike parametre za ocjenu. Stoga, za ove aktivnosti ne postoje univerzalni kriterijumi vrednovanja i njihov se kvalitet, uglavnom, procjenjuje individualno, ovisno o namjeni procjene. Bez obzira na manjkavosti, sistemi rangiranja univerziteta su važni komparativni parametri za procjenu kvaliteta naučne i edukativne vrijednosti univerziteta.

Ključne riječi: međunarodno priznati kriteriji, naučnoistraživački rad, edukacija, liste rangiranja univerziteta

\footnotetext{
* Ovaj rad je finansijski podržan od strane Federalnog ministarstva obrazovanja i nauke, Federacija Bosne i Hercegovine, kao dio naučno-istraživačkog projekta pod nazivom "Uticaj pandemije COVID-19 na naučnu produkciju, citiranost naučnika i rangiranje univerziteta u Bosni i Hercegovini"

** Redovni član Akademije nauka i umjetnosti Bosne i Hercegovine, Odjeljenje medicinskih nauka; Kantonalna bolnica "Dr. Safet Mujić", Mostar. E-mail: zerem@live.com

${ }^{* * *}$ Dr. sci., Odsjek za fiziku, Prirodno-matematički fakultet Univerziteta u Tuzli. E-mail: kunosic@gmail.com
}

Autor za korespodenciju: Enver Zerem 


\section{Uvod}

Malo je procesa i događaja u istoriji čovječanstva koji su više od nauke transformirale društvo i doprinijele opštem dobru. Dostignuto znanje stečeno naučnim istraživanjima je milijarde ljudi spasilo od siromaštva, potaknulo industrijalizaciju i masovne komunikacije neslućenih razmjera, iskorijenilo brojna oboljenja i omogućilo čovjeku da ostavi svoje otiske na mjesecu. Danas je nauka velika industrija koja proizvodi nova znanja, obično za rješavanje određenih problema ili pitanja s kojima se suočava čovječanstvo. Kao i svaka druga industrija, tako i naučna, koristi svoje alate i resurse - naučnike, novac i vrijeme - za stvaranje svojih proizvoda: naučnog znanja, koje se prezentira preko publikacija u naučnoj literaturi.

Tokom 20. vijeka, ali i početkom 21. finansiranje nauke sve više preuzimaju vlade i javni fondovi bogatih zemalja i internacionalnih korporacija. Najznačajniji javni fondovi i druge organizacije koje finansiraju većinu naučnih istraživanja, ujedno su i glavni potencijalni korisnici ishoda naučnih istraživanja, koji trebaju biti pretočeni u opšti društveni progres, te obezbjediti profit i održivost fondacija. Upravo to je razlog da se najviše finansijskih sredstava ulaže u istraživanja koja trebaju donijeti benefite vojnoj industriji i kompetitivne prednosti u ekonomiji. Spoznaja da su investicije u biomedicinskim istraživanjima pretočene u konkretni praktični napredak u više medicinskih disciplina, ostvarila je snažnu društvenu potporu za ulaganje javnih fondova u cilju podrške biomedicinskoj znanosti.

Velike investicije u nauku uglavnom su usmjerene u bazična naučna istraživanja, što nedvojbeno rezultira povećanjem baze znanja. Međutim, rezultati istraživanja dobijeni kroz bazična naučna istraživanja često nisu komparabilni s očekivanom brzinom primjene tih rezultata u praktičnim unapređenjima u industriji, društvenom progresu i javnom zdravlju. Usporeni rezultati primjene naučnih istraživanja nose rizike da potkopaju povjerenje u nauku, donesu negativne implikacije na finansiranje naučnih istraživanja i relativno usporavanje naučnih inovacija. Često je neophodno sprovesti dodatna, takozvana, translacijska istraživanja koja bi omogućila transfer znanja dobijenih fundametalnim istraživanjima ka njihovoj praktičnoj primjeni.

Treba napomenuti da fundamnentalna (bazična) naučna istraživanja imaju vrlo važno suštinsko značenje i društvenu vrijednost u proizvodnji novih informacija koje uvećavaju sveukupnu ljudsku znanost, te su korisna i kada nemaju neposredni opipljivi ishod na primjenjene djelatnosti. Također je logično pretpostaviti da sva temeljna naučna istraživanja imaju određenu vjerojatnost 
za generiranje opipljivih rezultata u praktičnoj djelatnosti, iako takvi ishodi mogu biti nepredvidljivi i udaljeni kako u vremenu tako i u sadržaju primjene (naprimjer, teorija opšteg relativiteta, koja je znanstveno dokazana 1916. godine, donijela je koristan ishod za javno dobro tek krajem 20. vijeka ${ }^{1}$.

Međutim, uprkos suštinskoj društvenoj vrijednosti znanja postignutim fundamentalnim naučnim istraživanjima, očito je da javne agencije i finansijski fondovi podržavaju naučna istraživanja s ciljevima usmjerenim na ishod, uključujući dobrobit za zdravlje i sprečavanje bolesti, unapređenja i inovacije u industriji i ekonomiji te povećanje profita i povrata ulaganja. Upravo zbog toga razvila se velika konkurencija među ponuđačima usluga (univerziteti i naučni instituti) koji konkuriraju za dobijanje grantova koji suportiraju naučnoistraživačke projekte. Svi univerziteti, a često i naučni instituti, su institucije koje uz naučnoistraživački rad imaju i važnu ulogu u edukaciji i odgajanju novih kadrova. Edukativna djelatnost univerziteta se, također, u visokom procentu finansira iz javnih fondova i državnih proračuna ${ }^{2}$.

Rad akademskog osoblja prije nekoliko decenija bio je mnogo lagodniji nego danas. Univerzitetski nastavnici imali su obavezu da se bave nastavom i drugim oblicima edukacije studenata. Neki od njih su radili na naučnoistraživačkim projektima koji nisu imali imperativan ishod niti rok završetka. Naprimjer, u Velikoj Britaniji univerzitetski nastavnici su imali ugovor po kome su obavezni da se bave nastavom, religijom i da održe najmanje četiri predavanja tokom akademske godine. Imali su i načelnu obavezu da se bave naučnoistraživačkim radom, ali bez preciznih kriterija za ocjenu rezultata istraživanja, niti roka za završetak istraživanja. Ipak, i u tako ležernoj atmosferi bez presije na naučnike i bez velikih ulaganja u infrastrukturu i istraživanja, naporan rad inovatora $i$ istraživački um znanstvenika ostvarili su neka epohalna otkrića (npr. Sir Godfrey Hounsfeld, otkriće računarske tomografije $)^{3}$. Dolaskom u premijersku fotelju Margaret Thatcher, u akademskoj zajednici Velike Britanije, a kasnije i cijele Evrope, uvode se nova pravila za univerzitetske nastavnike: petogodišnji obnovljivi ugovori prema precizno dogovorenim ciljevima i uslovima za obnovu ugovora prema kriterijima zasnovanim na scientimetrijskim parametrima.

Novi ugovori za univerzitetsko osoblje koje je uvela premijerka Margaret Thatcher nisu dočekani s oduševljenjem u akademskoj zajednici, ne samo kod neambicioznih univerzitetskih nastavnika nego čak i kod uglednih

\footnotetext{
${ }^{1}$ Ashby, 2003:1-42; Bowen \&Casadevall, 2015:11335-40.

${ }^{2}$ Horton, 1998:892.

${ }^{3}$ Hounsfield, 1973:1016-22
} 
naučnika i pronalazača epohalnih otkrića. Naprimjer, Max Perutz, suotkrivač strukture hemoglobina (sa Johnom Kendrewom), energično je zastupao stajalište da do otkrića poput njihovih nije moglo doći po novim principima tretiranja nauke kratkoročnim ugovorima, jer određeni pronalazak zahtijeva gotovo dvije decenije razvoja, nakon početnog otkrića, prije ulaska u rutinsku primjenu u praksi ${ }^{4}$. Brojni naučnici su tvrdili da negativni pritisci na naučne institucije i naučnike i vremenska ograničenja za istraživanja mogu doprinijeti relativnom usporavanju znanstvenih inovacija i dovesti do zanemarivanja edukativne/nastavne komponente $u$ radu univerziteta. Za razliku od definicije efikasnosti zasnovane na proizvodnji (output-input), ocjenjivanje prethodnih rezultata istraživanja naučnika i naučnih institucija, koji konkurišu na dobijanje grantova, mnogo je komplikovanije.

Međutim, bez proučavanja i praćenja ishoda ne može se saznati isplati li se ulaganje društva u istraživanje u odnosu na inpute i ne može se procijeniti efikasnost i učinkovitost naučnih institucija, kao i praktični značaj naučnih inovacija u usporedbi sa ulaganjima u istraživanje. Praćenje naučnih inputa, rezultata i ishoda može koristiti za procjenu produktivnosti naučnoistraživačkih institucija i može biti korisno u procjena budućih reformi i promjena politike. Da bi bio primjenjiv. sistem pokazatelja kvaliteta treba biti što jednostavniji i racionalniji u pogledu pružanja potrebnih informacija za adekvatnu procjenu kvaliteta istraživanja. Ovisno o kontekstu upotrebe, moguće je razlikovati različite aspekte kvaliteta. Kvalitet istraživanja ukazuje na korisnost rezultata istraživanja za naučnu zajednicu u okviru jedne ili više naučnih disciplina. Društveni kvalitet, koji sve više dobija na značaju, ukazuje na korisnost rezultata istraživanja za širu grupu: vladu, privredu i industriju, institucije kulture i civilnog društva. U stvarnoj praksi kvalitet naučnog istraživanja određuju nezavisni experti (takozvana "peer-review" recenzija) na osnovu internacionalnih scietimetrijskih parametara. U zavisnosti od namjene "peer-review" procjena može biti podržana i dopunjena drugim indikatorima kvaliteta koji se ne mogu izraziti scientimetriskim parametrima (dobijeni grantovi, uredništvo naučnih časopisa, pozicije u akademskoj zajednici, mentorstvo u naučnim projektima i doktoratima i slično).

\footnotetext{
${ }^{4}$ Kendrew\&Perutz, 1948:375-98.
} 


\section{Kriteriji za procjenu kvaliteta naučnog istraživanja}

Društveni značaj i kvalitet naučnog istraživanja u velikoj mjeri ovise o korisnosti rezultata istraživanja za društvenu i naučnu zajednicu. Nedostatak sredstava za naučna istraživanja i želja da se sredstva dodijele visokokvalitetnim istraživanjima čine sve značajnijim mjerenje i procjenu kvaliteta istraživanja i valorizacije znanja. Međutim, vrlo je teško primijeniti naučne kriterije koji mogu objektivno procijeniti naučna istraživanja, pružajući precizne kvalitativne i kvantitativne podatke na kojima bi agencije za financiranje mogle temeljiti svoje odluke.

Ključno pitanje, koje je uvijek u nauci i obrazovanju ostajalo nedorečeno, je na osnovu kojih kriterija se mjeri taj kvalitet, te kako se može osigurati ispunjenje standarda da svi daju adekvatni kvalitet izlaznih kompetencija. Pošto se naučno-istraživački rad preko inovacija, patenata i publikacija može puno egzaktnije mjeriti i evaluirati, u odnosu na edukativne i ostale djelatnosti zastupljene u visokom obrazovanju, ovi parametri se često pojavljuju kao predeterminirajuće mjere u evaluaciji kvaliteta visokog obrazovanja ${ }^{5}$.

$\mathrm{Na}$ kvalitet naučno-istraživačkog rada i na ukupnu naučnu produkciju evaluiranu kroz inovacije, patente i publikacije najviše utječu: nacionalni dohodak, procenat izdvajanja iz nacionalnog dohotka za naučno-istraživački rad, internacionalni kriteriji za valorizaciju naučnih istraživanja, uslovljenost akademskog napredovanja i znanstvene valorizacije i međunarodne naučne komunikacije.

Proizvod naučnog istraživanja uglavnom su informacije objavljene u naučnim časopisima i one su temelj širenja znanja, kao i osnovni kriterij za akademsku i naučnu evaluaciju, regrutovanje sredstava za naučna istraživanja i napredovanje u karijeri. Tačno je da, pored evaluacije naučnih publikacija, postoji i širok spektar drugih naučnih aktivnosti koji takođe odražavaju naučni kredibilitet znanstvenika, kao što su: broj i kvalitet grantova za naučnoistraživačke projekte, liderstvo u nacionalnim ili međunarodnim akademskim društvima, članstvo u redakcijama uglednih časopisa, služba u nacionalnim komitetima za ekspertnu provjeru naučnoistraživačkih projekata koje sponzorira država, mentorstva u doktorskim disertacijama, broj ekspertnih i tematskih članaka u takozvanoj laičkoj štampi i slično ${ }^{6}$.

Iako su te aktivnosti važne i daju određeni značaj naučnoj vjerodostojnosti znanstvenika, relevantni metrički znanstveni sistemi pokrivaju samo

\footnotetext{
${ }^{5}$ Dixon, 2009: 847-50; Zerem, 2017: 107-9;Zerem \& Kunosić, 2018: 133-4.

${ }^{6}$ Miles, 1991:643-5; Zerem, 2013:128.
} 
publikacije i izostavljaju druge kriterije od naučne važnosti, koje bi imalo smisla koristiti u ocjenjivanju prilikom akademskog napredovanja znanstvenika kao i konkursima za dobijanje grantova za finansijsku potporu naučnim istraživanjima. Razlog tome je činjenica da su ove aktivnosti, bez obzira na važnost, vrlo heterogene, jer svaka od njih ima specifične karakteristike i zahtijeva različite parametre za ocjenu. Stoga za ove parametre od naučne važnosti ne postoje univerzalni kriterijumi vrjednovanja i njihova se vrijednost uglavnom procjenjuje pojedinačno, ovisno o namjeni procjene ${ }^{7}$.

\section{Rangiranje univerziteta i odnos prema rangiranju u zemljama našeg regiona}

Borba za zauzimanje prestižnog mjesta na svjetskoj rang listi vrhunskih univerziteta sve više se rasplamsava i poprima karakteristike bitke za status i različite vrste dominacije najrazvijenijih zemalja svijeta. Ulažu se značajna finansijska sredstva u formiranje različitih internacionalnih listi rangiranja univerziteta. Relevantne liste rangiranja univerziteta uzimaju u obzir različite parametre, ali za većinu univerziteta (s djelimičnim izuzetkom prvih 100) najveći značaj pri rangiranju ima broj publikacija i utjecaj koje te publikacije ostvare citiranjem.

Najprestižnije liste rangiranja univerziteta u svijetu objavljuju svoje rezultate jednom ili dva puta godišnje. U akademskim zajednicama, pa i u medijima zemalja regiona, tim rezultatima se daje veliki značaj i oni budu propraćeni vrlo aktivno, nekada burno, a nekada čak i preemotivno u odnosu na racionalnost koja se očekuje od pripadnika akademskih zajednica. Neki univerziteti iz zemalja regiona, a to se $u$ prvom redu odnosi na Univerzitete $u$ Ljubljani, Beogradu i Zagrebu, ostvarili su tokom posljednjih godina značajan napredak na internacionalnim listama rangiranja. Akademske zajednice $u$ tim zemljama stalno evaluiraju i iznalaze mogućnosti za napredovanje svojih univerziteta na rang listama, a mediji analiziraju i upoređuju rezultate svojih univerziteta sa rezultatima drugih univerziteta u svijetu i posebno u regionu.

Paradoksalna je situacija u Bosni i Hercegovini. Nasuprot dugogodišnjem, u našoj javnosti već etabliranom, aksiomskom mišljenju da smo najbolji, svi naši univerziteti, ili nisu uopšte rangirani na internacionalnim listama, ili su rangirani značajno ispod univerziteta sličnog ranga u regionu. Koliko se u javnosti zna, nijedan osnivač (politički mentor) naših univerziteta nije tražio

\footnotetext{
${ }^{7}$ Marušić\&Marušić, 1999:1713-14; Zerem, 2014:248-51; Zerem, 2018:147-8.
} 
da, poboljšavanje pozicije na internacionalnim rang listama, bude uslov $u$ procjeni uspješnosti rada univerziteta čiji je osnivač, niti je na početku godine neki univerzitet to sebi postavio za cilj. Kako u ovakvoj atmosferi na univerzitetu i u društvu naći dovoljno snage koja stremi pravim (svuda u svijetu priznatim) vrijednostima i koja bi naše univerzitete mogla unaprijediti na svjetskim rang listama kvaliteta? ${ }^{8}$

\section{Zašto rangirati univerzitete?}

U nastojanju da se tradicionalni sistem obrazovanja učini otvorenijim i fleksibilnijim primjetan je korak ka njegovoj decentralizaciji, i to ne samo teritorijalnoj, nego i više funkcionalnoj, kao i jačanju autonomije u obrazovanju i edukaciji. U decentraliziranom obrazovnom sistemu upravljanje se provodi pomoću ciljeva i rezultata koji promovišu jednakost i reproduciraju zajedničku vrednosnu osnovu.

U tom procesu, posebno je komplikovana pozicija visokog obrazovanja, jer je naučno-istraživački rad njegov neminovni dio i bez tog dijela, visoko obrazovanje ostaje neinventivno i u nemogućnosti da opravda svoju svrhu. Pošto se naučno-istraživački rad, preko inovacija, patenata i publikacija može puno egzaktnije mjeriti i evaluirati u odnosu na edukativne i ostale djelatnosti zastupljene u visokom obrazovanju, ovi parametri se često pojavljuju kao predeterminirajuće mjere u evaluaciji kvaliteta visokog obrazovanja. Oponenti ovakvom načinu evaluacije univerziteta napominju da se na ovaj način ne ocjenjuje nastava, već samo naučni rad, pa ovaj način rangiranja univerziteta ne odražava sve parametre kvaliteta univerziteta, posebno one koji odražavaju savremenost i kvalitet programa, nastave i profesora. Ipak, većina se slaže da se te neregularnosti odnose samo na niskorangirane univerzitete kod kojih, relativno mali broj publikacija može uzrokovati statističke "artefakte", dok je za publikovanje velikog broja značajnih znanstvenih publikacija, što je karakteristika visokorangiranih univerziteta, potrebno postići adekvatan kvalitet i u ostalim segmentima djelatnosti 9 .

Globalne rang-liste su izložene čestim kritikama i negodovanju, posebno od strane onih koji su nezadovoljni pozicijom svojih univerziteta pri rangiranju i evaluacijama na raznim nivoima, ali je činjenica da za sada nisu ponuđene eventualne alternative ovom trendu. Zato je logično zaključiti da, uprkos stalnim promjenama i evoluciji u dizajnu rangiranja akademskog kvaliteta,

\footnotetext{
${ }^{8}$ Zerem, 2013:128; Zerem, 2014:248-51.

${ }^{9}$ Petković, 2013; Zerem, 2014:248-51.
} 
kao i ostalih manjkavosti, analize sistema rangiranja pokazuju da oni postaju dio realnosti i rada hiljada univerziteta u svijetu.

Uporedive informacije o institucijama visokog obrazovanja, njihovom podučavanju i istraživačkim programima treba da olakšaju studentima i istraživačima da odaberu gdje i šta studirati i gdje raditi. Bolja informisanost također bi pomogla i onima koji donose politike na institucionalnom, nacionalnom i evropskom nivou, u razvijanju buduće strategije za visoko obrazovanje. Trenutna, u najvećoj mjeri jednodimenzionalna rangiranja, ne ispunjavaju ove svrhe jer imaju tendenciju fokusiranja na određene aspekte istraživanja i na cijele institucije, a ne na individualne programe i discipline. Ovakav pristup zahtijeva nove oblike upravljanja i programiranja naučnoistraživačkog i edukativnog rada. Glavni cilj u tom pravcu je uspostaviti efikasan i fleksibilan sistem akreditacije davalaca/organizatora obrazovnih usluga i certificiranja stečenih znanja i vještina. ${ }^{10}$

\section{Postojeći sistemi rangiranja univerziteta}

Rangiranje univerziteta bi trebalo da obuhvati kriterijume kao što su: obrazovanje, istraživanje, kvalitet nastavnika, međunarodnu saradnju i sredstva (finansije) koje ostvaruju univerziteti svojim radom. Relevantna su mjerila koja se mogu izraziti kvantitativno, kao što su: broj upisanih studenata, procenat diplomiranih studenata, odnos broja nastavnika i broja studenata, broj doktorskih disertacija, nagrade kako nastavnika tako i studenata i "alumni" studenata, citiranost, broj radova objavljenih na SCI ili SSCI listi, broj patenata, broj međunarodnih časopisa koje univerzitet ili fakultet izdaje, broj stranih autora u tim časopisima, web sajt i dostupni web servisi, univerzitetske biblioteke, opremljenost laboratorijskog i učioničkog prostora itd. Važna mjerila kvaliteta univerziteta su i prihodi koji se ostvaruju od školarine, sredstva koja se ostvaruju iz državnih fondova, sredstva koja potiču od fondova EU itd. Jedan od veoma važnih kriterijuma je i međunarodna saradnja gdje bi se vršila analiza o broju stranih studenata koji studiraju na univerzitetu kao i broj studenata koji je otišao da studira na druge univerzitete (mobilnost studenata). Isto tako, za ukupnu ocjenu rada univerziteta značajan je broj gostujućih profesora na univerzitetu, kao i broj profesora izabranih na tom univerzitetu koji su izabrani u zvanje gostujućeg profesora na drugim univerzitetima.

\footnotetext{
${ }^{10}$ Petković, 2015.
} 
Iako je broj sistema za rangiranje univerziteta svake godine sve veći, četiri su najznačajnije i najreprezentativnije liste, koje rangiraju univerzitete na nivou cijelog svijeta koristeći različite parametre i načine bodovanja. Najznačajnije liste rangiranja univerziteta su: Šangajska lista,The times higher education supplement - THES, WEBOMETRICS rangiranje i SCImago rangiranje ${ }^{11}$.

\section{Šangajska lista}

Akademsko rangiranje svjetskih univerziteta (the Academic Ranking of World Universities) (ARWU) prvi je put objavljeno u junu 2003. godine. Pedagoški fakultet Univerziteta Shanghai Jiao Tong, Kina, ažurira ovu listu svake godine. ARWU koristi šest objektivnih indikatora za rangiranje univerziteta, uključujući broj alumnija i profesora koji su osvojili Nobelovu nagradu i medalje za određene oblasti, broj visokocitiranih istraživača u časopisima koji su citirani u bazi Thomson Scientific (sada "Clarivate Analytics journal list"), broj članaka objavljenih u časopisima "Nature" i "Science", broj članaka indeksiranih u Science Citation Index - Expanded i u Social Sciences Citation Index, te učinak per capita u odnosu na veličinu institucije. Svake godine ARWU rangira više od 1000 univerziteta, a najboljih 500 objavljuje na mreži.

\section{The Times higher education supplement - THES}

Časopis Times u dodatku o visokom obrazovanju - THES (The Times Higher Education Supplement) rangira univerzitete od 2004. godine. THES rangiranje se bazira na četiri kriterijuma za koje se smatra da reprezentuju kvalitet rada univerziteta $i$ to: visokokvalitetno istraživanje, visokokvalitetna nastava, visoka stopa zaposlenosti diplomiranih i dobar "internacionalni imidž". Problem ovakvog načina rangiranju su neki kriteriji koji su objektivno teško mjerljivi kao što je naprimjer kriterij visokokvalitetna nastava.

\section{WEBOMETRICS rangiranje}

Rangiranje univerziteta na listi Ranking Web of World universities je inicijativa laboratorija Cybermetrics (Cybermetrics Lab), istraživačke grupe Centra za humanističke i društvene nauke (Centro de Ciencias Humanas y

\footnotetext{
${ }^{11}$ Hall,1998:1230; Klaic,1997:88-98.
} 
Sociales - CCHS), u sastavu National Research Council - CSIC u Španiji. Laboratorij "Cybermetrics" rangira univerzitete na osnovu kvantitativne analize sadržaja na internetu i webu, posebno onih koji su povezani s procesima nastave i akademske komunikacije. Ovim rangiranjima tim webometricsa želi istraživače širom svijeta dodatno motivisati da objavljuju više i kvalitetnije naučne sadržaje na webu, te da ih učine dostupnim kolegama $i$ drugim zainteresovanim u cijelom svijetu. Rangiranje svjetskih univerziteta "Webometrics" službeno je pokrenuto 2004. godine i ažurira se svakih 6 mjeseci (podaci se prikupljaju u januaru i julu, a objavljuju jedan mjesec kasnije).

\section{SCImago rangiranje}

SCImago je istraživačka grupa koja se bavi informatičkom analizom u različitim oblastima. Čine je Institut za politiku i javne poslove Nacionalnog istraživačkog vijeća Španije (CSIC), SCImago Institut i više univerziteta (Univerzitet u Granadi, Univerzitet Carlos III u Madridu, Univerzitet Ekstramadura, Univerzitet Alcala de Hanares i Univerzitet Porto). SCImago Institutional Ranking - SIR je globalna lista rangiranja koja rangira institucije iz sfere RDI (univerziteti, fakulteti, instituti, istraživački centri, bolnice, poslovne kompanije i sl.) koje imaju najmanje 100 indeksiranih publikacija na godišnjem nivou. U SIR tabelama rangiranja visokoškolske organizacije i RDI institucije su rangirane na bazi ukupnog broja publikacija na bazi pretraživanja u bazi podataka SCOPUS ${ }^{12}$.

\section{Rangiranje univerziteta u Bosni i Hercegovini}

Univerziteti i fakulteti u $\mathrm{BiH}$ su sve više edukacijske, a sve manje naučne institucije, te simboliziraju miks srednjeg i visokog obrazovanja, ne postajući niti jedno niti drugo, u prvom smislu riječi. Prije posljednjeg rata 1992-1995. godine u BiH su postojala 4 javna univerziteta (Sarajevo, Tuzla, Mostar i Banja Luka). Bosanskohercegovački fakulteti i univerziteti su u tom periodu, uglavnom, nastajali iz već postojećih naučnih institucija (najčešće instituta), koje su se godinama prije toga bavili naučno-istraživačkim radom. Fakulteti su se osnivali na logičan način kojim su instituti, kao već respektabilne naučne institucije, dobijali i svoju obrazovnu ulogu, te na taj način prerastali u fakultete za tu naučnu oblast.

\footnotetext{
${ }^{12}$ Brennan-Krohn, 2011.
} 
Šta se dogodilo sa našom akademskom zajednicom u toku i nakon posljednjeg rata? Ukoliko nam je rat mogao biti izgovor za određene propuste u prvim poslijeratnim godinama, teško da nam to može biti opravdanje i 25 godina nakon rata. Zbog čega nismo u međuvremenu uspjeli vratiti onu poziciju i značaj visokom obrazovanju kakvu ono zaslužuje? Najkraći odgovor na ovo pitanje bio bi: nismo uspjeli uvesti kriterije, kojima bi nekontrolisano-rastući kvantitet visokoškolskih ustanova pretvorili u kvalitet ${ }^{13}$.

Tako, tokom 2002. godine u sistemu bosanskohercegovačkog visokog obrazovanja prisutne su 43 institucije visokoškolskog obrazovanja u rangu univerziteta/koledža ili samostalnih fakulteta (10 javnih univerziteta/fakulteta i 33 u privatnom vlasništvu), a 2012. godine u BiH egzistira 25 univerziteta sa 177 fakulteta, 10 akademija i 4 vjerska fakulteta. Od tada broj visokoškolskih ustanova u našoj zemlji stalno raste. Međutim, taj nekontrolisani rast broja visokoobrazovnih institucija nije ni približno praćen porastom znanstvene produkcije, koju bi od tolikog broja univerziteta i fakulteta bilo logično očekivati. Naučno-istraživački rad i znanstvene publikacije kao njegova najrelevantnija evaluacijska konfirmacija su osnovna pokretačka energija visokog obrazovanja. Bez te pokretačke energije, naše visoko obrazovanje postalo je teški bolesnik kome se "krv pretvara u vodu" (ili znanost zamjenjuje politikantstvom), svedeno na puku obrazovnu komponentu koju sprovode nekompetentni protagonisti.

Ako primijenimo liste rangiranja, opisane u ovom članku (Šangajska lista, The Times higher education supplement - THES, SCImago rangiranje, Webometrics list) na naše univerzitete, treba napomenuti da su naši univerziteti rangirani samo na Webometrics listi. Ostale tri liste rangiraju, direktno, samo univerzitete koji su rangirani do hiljaditog mjesta na njihovim listama i na njima se ne prezentira niti jedan naš univerzitet. Webometrics rangira dva puta godišnje (januar i juli), praktično sve prijavljene univerzitete (preko 30.000 univerziteta i fakulteta) na osnovu edukativnih i znanstvenih kriterija. Ti kriteriji kontinuirano evoluiraju i u manjoj mjeri se mijenjaju, ali u suštini ostaju navedene (edukativna i znanstvena) komponente, koje su osnova Webometrics rangiranja.

Na Slici 1. prikazano je rangiranje najuspješnijih univerziteta u $\mathrm{BiH}$ od 2014. do 2021. godine, pri čemu su prikazani presjeci za oba godišnja rangiranja (januar i juli). Univerzitet u Sarajevu je jedini naš univerzitet koji je na Webometricsovoj listi pozicioniran među 2000 najboljih univerziteta (između

${ }^{13}$ Zerem, 2013:128; Zerem, 2014:248-51 
1500. i 2000. mjesta) u svijetu, izuzev u julu 2015. i 2018. godine, kada je bio pozicioniran ispod 2000. mjesta. Činjenica je da je Sarajevski univerzitet naš najbolje rangirani univerzitet, ali je isto tako činjenica da je niže rangiran u odnosu na sve javne univerzitete u Sloveniji, Hrvatskoj (izuzev Univerziteta u Osijeku) i Srbiji. Isto tako, na grafikonu je uočljivo da u posmatranom periodu stagnira, ne pokazujući tendenciju napretka koji bi ga doveo u poziciju da bude rangiran i na ostalim listama rangiranja. Tako skromna pozicija našeg najvećeg univerziteta, s ubjedljivo najvećim resursima i budžetom, imala je negativan impakt na razvoj nauke, drugih naših univerziteta i visokog obrazovanja u našoj zemlji.

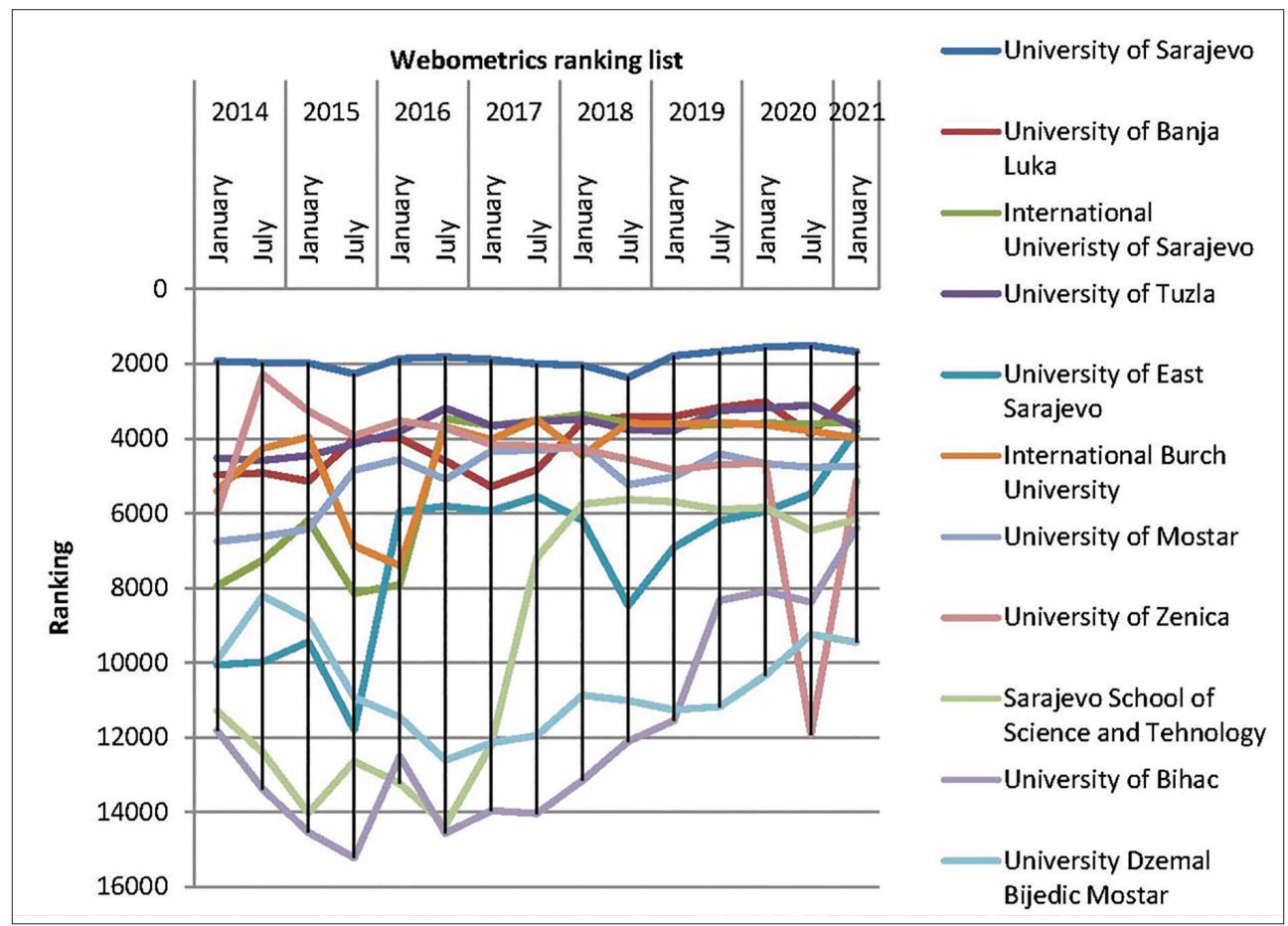

Slika 1. Prikaz najuspješnijih univerziteta u BiH na webometrics listi za period 2014-2021.

Univerzitet u Banjoj Luci je drugorangirani univerzitet u našoj zemlji na posljednjoj (januar, 2021. godine) listi rangiranja i uz Sarajevski je jedini naš univerzitet rangiran u 3000 najuspješnijih univerziteta. $U$ analiziranom periodu (od 2014. godine) Banjalučki univerzitet pokazuje postepeni rast i s 4977. mjesta dostigao je 2658. mjesto, a u rangiranju naših univerziteta s četvrtog na drugo mjesto. Univerzitet u Tuzli je bio drugorangirani univerzitet u $\mathrm{BiH}$ 
do kraja 2016. godine, da bi nakon toga bio pozicioniran između 3500. i 4000. mjesta na ukupnoj Webometricsovoj listi i pomjeren s drugog na četvrto mjesto u konkurenciji naših univerziteta ${ }^{14}$. Ostali naši javni univerziteti bili su locirani iza 4000. mjesta na Webometricsovoj listi u analiziranom periodu s povremenim kratkotrajnim uzlaznim trendovima (Zenica 2014. godine), koji su bili više rezultat prilagođavanja trenutnim kriterijima Webometrics liste, nego kontinuiranog objektivnog kvaliteta. Na grafiku se uočava da su najveći nominalni napredak u analiziranom periodu ostvarili Univerzitet u Istočnom Sarajevu (za 6270 pozicja) i Univerzitet u Bihaću (za 5412 pozicija). Iako je njihov uspjeh, fokusirajući se samo na brojeve impozantan, ako posmatramo pozicije tih univerziteta $\mathrm{s}$ trendom izmjena kriterija na Webometricsovoj listi prikazanoj na Tabeli 1, koje ne idu u prilog malim univerzitetima, trebamo zadržati rezervu prema daljem napredovanju, na Webometrics listi, ovih univerziteta.

Od privatnih univerziteta $\mathrm{u} \mathrm{BiH}$ najbolje je pozicioniran International University of Sarajevo, koji je ujedno i treći najbolje pozicionirani univerzitet u BiH. Ovaj univerzitet prezentira činjenicu da je selekcioniranje kadrova i kolaboracija s kadrovski moćnijim matičnim univerzitetom dobar recept za solidan uspjeh u konkurenciji naših univerziteta. Sličan način rada sa sličnim rezultatima do 2016. godine ima i International Burch University. Nakon 2016. godine, International Burch University ima određene kadrovske probleme što se odražava i padom na listi rangiranja.

U rangiranju za januar 2021. izmijenjena je metodologija rangiranja koju koristi Webometrics tako da su za rangiranje univerziteta korištena samo 3 kriterija (Tabela 1). Na slikama 2, 3. i 4. prikazano je rangiranje naših najuspješnijih univerziteta po svakom od tri kriterija odvojeno. Na tim slikama su prikazane neke činjenice koje objektivnije prezentiraju kvalitet rada naših univerziteta. Najuočljivija je činjenica da prema kriteriju "Impact Rank" dva privatna univerziteta (Evropski univerzitet Brčko i Evropski univerzitet Kallos) koji imaju istog vlasnika, rangirani su na prvom i trećem mjestu u konkurenciji naših univerziteta. Istovremeno, u rangiranju "Openness Rank" i "Excellence Rank" nijedan od ta dva univerziteta nije rangiran u prvih 10 u konkurenciji naših univerziteta. Ove činjenice svakako zahtijevaju podrobniju analizu, ali se i bez analize može reći da postoji velika zainteresovanost nekih privatnih univerziteta za brže napredovanje na listama rangiranja koje nije u skladu sa njihovim realnim kvalitetom i nedovoljnu zainteresovanost nekih drugih, u prvom redu javnih univerzioteta.

\footnotetext{
${ }^{14}$ Kunosić, S., Čeke, D., Zerem, E, 2019; Čeke\&Kunosić, 2021.
} 
Tabela 1. Webometrics university ranking methodology (January edition, 2021)

\begin{tabular}{lllll}
\hline INDICATORS & MEANING & METHODOLOGY & SOURCE & WEIGHT \\
\hline PRESENCE & & This indicator has been discontinued & \\
\hline VISIBILITY & $\begin{array}{l}\text { Web contents } \\
\text { Impact }\end{array}$ & $\begin{array}{l}\text { Number of external networks (subnets) linking to } \\
\text { the institution's webpages (normalized and then the } \\
\text { maximum value is chosen) }\end{array}$ & $\begin{array}{l}\text { Ahrefs } \\
\text { Majestic }\end{array}$ & $\mathbf{5 0 \%}$ \\
\hline $\begin{array}{l}\text { TRANSPARENCY } \\
\text { (or OPENNESS) }\end{array}$ & $\begin{array}{l}\text { Top cited } \\
\text { researchers }\end{array}$ & $\begin{array}{l}\text { Number of citations from Top 210 authors (excl. top } \\
\text { 20 outliers) }\end{array}$ & $\begin{array}{l}\text { Google Scholar } \\
\text { Profiles }\end{array}$ & $\mathbf{1 0 \%}$ \\
\hline $\begin{array}{l}\text { EXCELLNCE } \\
\text { (or SCHOLAR) }\end{array}$ & $\begin{array}{l}\text { Top cited } \\
\text { papers }\end{array}$ & $\begin{array}{l}\text { Number of papers amongst the top 10\% most cited in } \\
\text { each one of the all 27 disciplines of the full database } \\
\text { Data for the five year period: 2015-2019 }\end{array}$ & Scimago & $\mathbf{4 0 \%}$ \\
\hline
\end{tabular}

Novom metodologijom Webometrics je ujednačio procenat težina između edukativnih i znastavenih kriterija. Osim toga iz godine u godinu Webometrics povećava uticaj znastvenih kriterija koji utiču na rangiranje univerziteta $u$ cijelom svijetu. Izmjena kriterija je značajno uticala i na pozicije pojedinih univerziteta u $\mathrm{BiH}$ što se jasno vidi na slikama 2, 3. i 4.

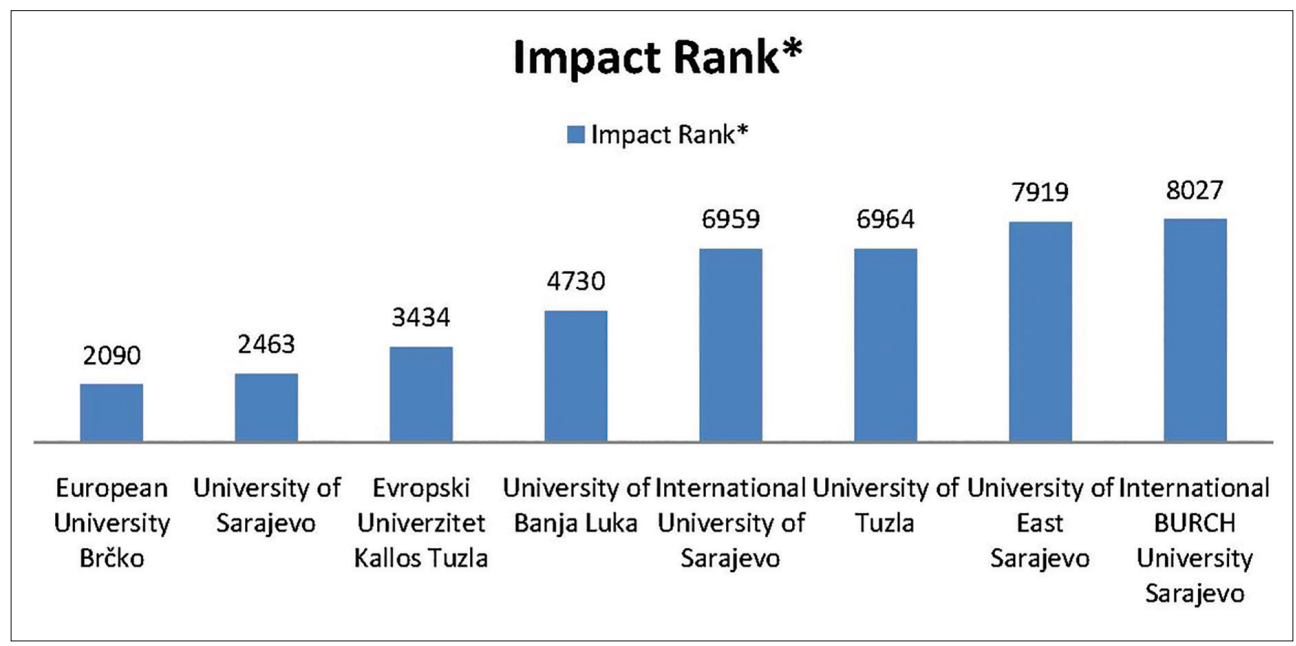

Slika 2. Prikaz najuspješnijih univerziteta u BiH po kriteriju "Impact rank" za januar 2021.

Prema "impact ranku” (Slika 2) najbolje je pozicioniran Europen University Brčko, a među 8 najboljih u ovoj kategoriji su 4 privatna univerziteta. Uočljivo je da javni univerziteti u $\mathrm{BiH}$ imaju mnogo prostora za napredovanje prema ovom kriteriju rangiranja po kojem se objektivno može najbrže i najlakše napraviti progres na listi rangiranja 


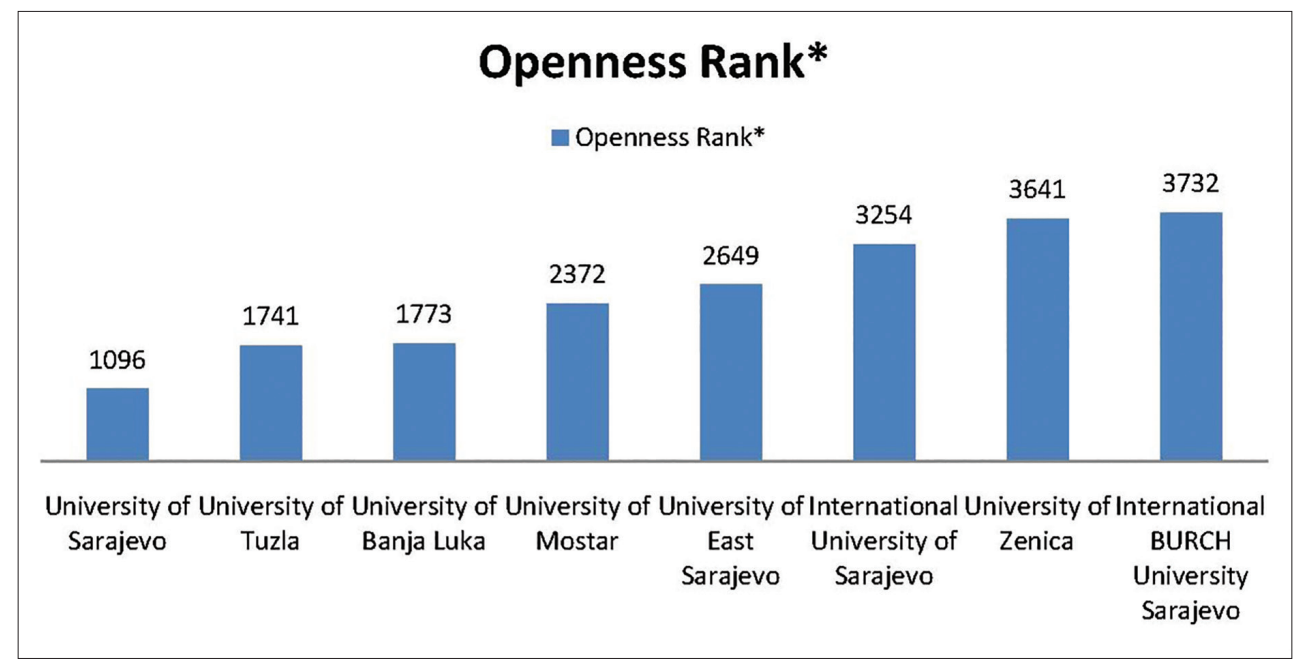

Slika 3. Prikaz najuspješnijih univerziteta u BiH po kriteriju "Openness rank" za januar 2021.

Za razliku od prethodnog kriterija "Impact Rank", prema kriteriju “Opennness Rank” tj. broju citata naučnika s google scholar na Slici 3. uočljiva je prednost javnih univerzieta, među kojima prednjače univerziteti koji imaju više zaposlenih znanstvenika.

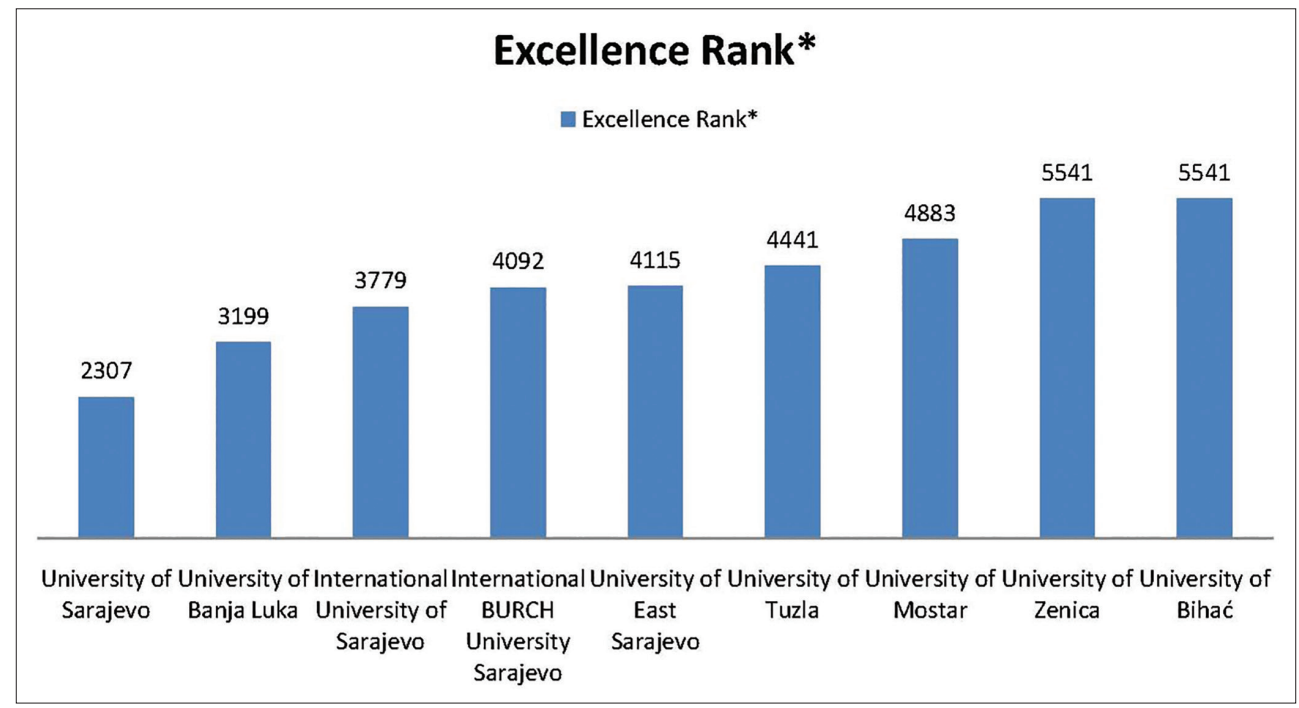

Slika 4. Prikaz najuspješnijih univerziteta u BiH

po kriteriju "Exellence rank" za januar 2021. 
Najznačajniji znastveni kriterij "exellence rank" koji je zastupljen s 40 procenata od ukupnog scora na Webometrics rangiranju, a prva tri mjesta rangiranja univerziteta $\mathrm{u} \mathrm{BiH}$ po ovom kriteriju identična su kao i prve tri pozicije na ukupnoj Webomwtricsovoj listi (Slika 1. i 4).

U izvještaju SJR: Scimago za period 1996-2019. godina (Slika 5). Bosna i Hercegovina zauzima 95. mjesto u svijetu po broju objavljenih naučnih članka, ali s nižom stopom citiranosti od Makedonije koja ima manji broj publiciranih članka. Najbolju poziciju na listi zauzima Hrvatska koja je na 50. poziciji, Slovenija (52. mjesto) i Srbija (53. mjesto) Slovenija ima najveći broj citata i najveći $H$ index u odnosu na sve ostale države koje su nastale nakon raspada Jugoslavije.

\begin{tabular}{|r|l|r|r|r|r|r|r|}
\hline Rank & Country & Doc & Citable doc & Citations & Self-citat & Citat per doc & H index \\
\hline 50 & Croatia & 113256 & 107688 & 1146885 & 197804 & 10,13 & 282 \\
\hline 52 & Slovenia & 101460 & 96022 & 1490029 & 224168 & 14,69 & 310 \\
\hline 53 & Serbia & 101388 & 95763 & 989159 & 184758 & 9,76 & 247 \\
\hline 95 & Bosnia and Herzegovina & 13884 & 12961 & 94225 & 9735 & 6,79 & 103 \\
\hline 97 & Macedonia & 12815 & 12117 & 133726 & 12137 & 10,44 & 121 \\
\hline 123 & Montenegro & 4717 & 4474 & 32182 & 5984 & 6,82 & 64 \\
\hline
\end{tabular}

Slika 5. Analiza broja članaka, citata, H indexa za prema listi SJR:

Scimago za period 1996-2019. godina.

Međutim, kada se napravi analiza broja dokumenata i citata po stanovniku (Slika 6), Bosna i Hercegovina je na posljednjem mjestu, u konkurenciji zemalja slijednica bivše Jugoslavije i prema broju dokumenata i prema broju citata. Podaci navedeni na slikama 5. i 6, jasno ukazuju da je u poslijeratnom periodu Bosna i Hercegovina najviše zaostajala u važnim parametrima koji prezentiraju stanje nauke u određenoj državi ili društvenoj zajednici.

\begin{tabular}{ll}
\hline \multicolumn{2}{c}{ Number of Articles per population } \\
\hline Slovenia & 0,049 \\
\hline Croatia & 0,026 \\
\hline Serbia & 0,014 \\
\hline Montenegro & 0,008 \\
\hline Macedonia & 0,006 \\
\hline Bosnia and Herzegovina & 0,004 \\
\hline
\end{tabular}

\begin{tabular}{ll}
\hline \multicolumn{2}{c}{ Number of quotations per population } \\
\hline Slovenia & 0,713 \\
\hline Croatia & 0,268 \\
\hline Serbia & 0,141 \\
\hline Montenegro & 0,064 \\
\hline Macedonia & 0,052 \\
\hline Bosnia and Herzegovina & 0,027 \\
\hline
\end{tabular}

Slika 6. Broj članka i citata po stanovniku, a prema listi SJR:

Scimago za period 1996-2019. godina. 
Zbog čega nismo uspjeli kontrolisati taj nagli porast broja fakulteta, univerziteta i naučnika i usaglasiti ga s realno očekivanom znanstvenom produkcijom koja je to trebala pratiti i biti mu nužni korektiv?

Prvo treba pomenuti objektivne uzroke. Svi univerzitetski centri u Bosni i Hercegovini su, odmah na početku rata (ali i tokom cijelog rata pa i kasnije), ostali bez značajnog broja kadrova, koji su do tog momenta bili nosioci aktivnosti na tim univerzitetima. Te kadrove bilo je nužno zamijeniti drugim nastavnicima da bi se održalo funkcionisanje univerziteta u ratnim uslovima. Normalno je i očekivano da te zamjene u ratnim uslovima, vrlo često, nisu bile adekvatne. Međutim, nakon toga se pravi odlučujuća greška. Akademska zajednica se ne uspijeva suprotstaviti propagandi i stvaranju opšte klime, da se u akademskoj zajednici trebaju napustiti etablirani i univerzalni internacionalni znanstveni kriteriji i uvesti lokalni kriteriji koji su jedino primjereni za zemlju u ratnim uslovima. Uvođenjem lokalnih kriterija, ratom izolovana akademska zajednica, postaje meta lokalne politike, koja počinje sa sve frekventnijim ‘ubacivanjem' svojih kadrova koji po novim kriterijima, potpuno ispunjavaju uslove. To dovodi do slabljenja uticaja nauke, kao osnovne pokretačke snage akademske zajednice i jačanja uticaja politike u našim visokoškolskim institucijama.

Jedan dio odgovora sadržan je u Dejtonskoj postavci položaja obrazovanja, pa tako i visokog obrazovanja u našoj zemlji, gdje o radu pa i o osnivanju novih visokoškolskih ustanova odlučuju entitetske, a u Federaciji čak kantonalne političke strukture. Te strukture su pokazale potpunu nekompetentnost da odlučuju o tako sofisticiranim problemima, bez razumjevanja suštine funkcionisanja visokog obrazovanja. To se odnosi i na sredine kao što su Sarajevo, Banjaluka, Tuzla i Mostar koji su bili univerzitetski centri i prije rata. Sa druge strane, mali kantoni, koji su ranije jedva održavali sistem srednjeg obrazovanja dobili su pravo da osnivaju univerzitete i postali su pravi eldorado za privatne fakultete nekontrolisanog i sumnjivog kvaliteta i lokalne moćnike željne univerzitetske slave. Neki kantoni otvorili su po nekoliko privatnih fakulteta, pa čak i univerziteta, prije nego što su donijeli Zakon o visokom obrazovanju. Znači te ustanove su praktično radile prema svom vlastitom nahođenju, bez ikakve zakonske pa i suštinske kontrolne regulative ${ }^{15}$. Sve navedeno, dovelo je do prave poplave naučnih zvanja i nastavnih titula koje nisu niti u kakvoj korelaciji s realnom znanstvenom produkcijom ${ }^{16} . \mathrm{Na}$ taj način studenti dobijaju već u startu pogrešnu poruku pa se ne identificiraju

\footnotetext{
${ }^{15}$ Zerem, 2014:248-51

${ }^{16}$ Zerem, E., Kunosić, S., Imširović, B., \& Kurtčehajić, A. 136-142.
} 
s nastavnicima koji su ostvarili znanstvena dostignuća, nego se usmjeravaju na dobijanje naučnih titula bez nauke i što brži uspon u karijeri bez objektivnih pokazatelja znanstvene izvrsnosti. Postavlja se pitanje da li sada uopšte vrijedi uvesti neke standarde u visoko obrazovanje, jer smo mi već nafabrikovali kadrove po dosadašnjim kriterijima, koji će biti aktivni bar do 2040. godine ${ }^{17}$.

\section{Perspektive i zaključna razmatranja}

Društveni značaj i kvalitet naučnog istraživanja u velikoj mjeri ovise o korisnosti rezultata istraživanja za društvenu i naučnu zajednicu. Nedostatak sredstava za naučna istraživanja i želja da se sredstva dodijele visokokvalitetnim istraživanjima čine sve značajnijim mjerenje i procjenu kvaliteta istraživanja i valorizacije znanja.

Međutim, u nauci i obrazovanju uvijek je ostajalo otvoreno pitanje, koji kriteriji mogu objektivno procijeniti kvalitet rada visokoškolskih ustanova i tako osigurati ispunjenje standarda koji daju adekvatan kvalitet izlaznih kompetencija. Pošto se naučnoistraživački rad preko inovacija, patenata i publikacija može puno egzaktnije mjeriti i evaluirati, u odnosu na edukativne i ostale djelatnosti univerziteta, ovi parametri se često pojavljuju kao predeterminirajuće mjere u evaluaciji kvaliteta visokog obrazovanja.

U sadašnjoj situaciji, kada niti u jednom segmentu našeg visokoškolskog obrazovanja ne postoji dovoljan nivo znanja, posvećenosti i opredjeljenosti ka preduzimanju sistemskih mjera za poboljšanje kvaliteta rada naših visokoškolskih institucija, teško je reći koje bi mjere trebalo preduzeti da bi se to stanje popravilo, te da bi naši univerziteti napredovali na listama rangiranja. Jasno je, da se u kriterijima za formiranje listi rangiranja univerziteta mogu pronaći brojne manjkavosti, ali da sistemi rangiranja, htjeli mi to prihvatiti ili ne, postaju dio realnosti postojanja i rada hiljada univerziteta u svijetu.

Činjenica je da investicije u naučno-istraživački rad utiču na poboljšanje znanstvene produkcije. Ali, bez uvođenja međunarodno-priznatih naučnih kriterija u evaluaciji naučnih istraživanja, i koordinacije akademskog napretka u skladu s kriterijima, čak i trenutačne mizerne investicije u nauku su u biti beskorisno trošenje novca poreznih obveznika. Drugi, ne manji, važan razlog za ovakvo stanje našeg visokog obrazovanja i nauke, je njegova rascjepkanost i spuštanje nadležnosti nad njima na entitete i kantone, koji su potpuno

\footnotetext{
${ }^{17}$ Zerem, 2013;38:128; Zerem, 2014:248-51.
} 
nekompetentni za tu ulogu. Postojanje efektivne regulatorne institucije na nivou Bosne i Hercegovine, koja bi utvrđivala jedinstvene kriterije u visokom obrazovanju na nivou cijele države sa posjedovanjem kompentencija i mehanizma za efektivan nadzor njihovog sprovođenja, doprinijelo bi popravljanju stanja u nauci i visokom obrazovanju..

\section{Reference}

1. Ashby, N. (2003). Relativity in the Global Positioning System. Living Rev Relativ. Vol. 6(1):1. DOI: 10.12942/lrr-2003-1

2. Bowen, A., Casadevall A. (2015). Increasing disparities between resource inputs and outcomes, as measured by certain health deliverables, in biomedical research. Proc Natl Acad Sci U S A. 112(36):11335-40. DOI: 10.1073/pnas.1504955112.

3. Brennan-Krohn, Z. The Bologna Process in Bosnia-Herzegovina: Strengthening, ReBranding, or Undermining Higher Education? In: 1st International Conference on Foreign Language Teaching and Applied Linguistics (FLTAL), Sarajevo/Bosnia and Herzegovina, 5-7 May 2011.

4. Dixon, A.K. (2009) Publishing and academic promotion. Singapore Med J. 50(9):847-50.

5. Hall, T. (1998) The haunted forest: a ghost story. Lancet 352:1230. DOI: 10.1016/S01406736(05)60578-8.

6. Horton, R. Publication and promotion. A fair reward. Lancet. 352:892. DOI: 10.1016/ S0140-6736(05)60578-8

7. Hounsfield, G.N. (1973) Computerized transverse axial scanning (tomography). 1. Description of system. Br J Radiol 46:1016-22. DOI: 10.1259/0007-1285-46-552-1016

8. Kendrew, J.C., Perutz, M.F. (1948). A comparative X-ray study of foetal and adult sheep haemoglobins. Proc R Soc Lond A Math Phys Sci 194:375-98. DOI: 10.1098/ rspa.1948.0087.

9. Klaic, B. (1997). Analysis of scientific prodictivity in Croatia according to the Science Citation Index, Social Science Citation Index, and Arts \& Humanities Citation Index for the 1980-1995 period. Croat Med J. 38:88-98.

10. Kunosić, S., Čeke, D., Zerem, E.: Advantages and disadvantages of the webometrics ranking system. In: Kunosić, S., Zerem, E., (eds.) Scientometrics Recent Advances (2019). https://www.intechopen.com/books/scientometrics-recent-advances/advantagesand-disadvantages-of-the-webometrics-ranking-system

11. Čeke D and Kunosić S. (2021) Analiza kvalitete naučno-istraživačkog rada bazirana na citiranosti naučnih radnika i rangiranosti univerziteta u Covid-19 vremenu u Bosni i Hercegovini. Quality 2021 (S.Brdarević, S. Jašarević, editors)”, ISSN 1512-9268, Neum, B\&H, 17-19 June 2021., pp. 17-22

12. Marušić, A., Marušić M. (1999). Authorship criteria and academic reward. Lancet 353:1713-14

13. Miles, K.A., Hayball, M., Dixon, A.K. Colour perfusion imaging: a new application of computed tomography. Lancet 1991; 337:643-5. DOI: 10.1016/0140-6736(91)92455-b.

14. Petković,B., Petković,D., Ćatić, R. (2013). Kako povezati sistem osiguranja kvaliteta u visokom obrazovanju sa aspekta postojećih sistema rangiranja univerziteta. Naučnostručni skup sa međunarodnim učešćem "QUALITY 2013”, Neum, B\&H, 06. - 08. juni 2013. 
15. Petković, B., Pehlić, I., Ćatić, R. Petković, D. Analiza spremnosti BH visokoškolskih organizacija za procese međunarodnih rangiranja rangiranja. Naučno-stručni skup sa sa međunarodnim učešćem "QUALITY 2015", Neum, B\&H, 10. - 13. juni 2015.

16. Zerem, E. (2013). Right criteria for academia in Bosnia and Herzegovina. Lancet. 382:128. DOI: $10.1016 / \mathrm{S} 0140-6736(13) 61565-2$

17. Zerem, E. (2014). Academic community in a developing country: Bosnian realities. Med Glas (Zenica). 11:248-51.

18. Zerem, E. (2017). The ranking of scientists based on scientific publications assessment. J Biomed Inform. 75:107-109. DOI: 10.1016/j.jbi.2017.10.007.

19.Zerem, E. (2018). The ranking of scientists. J Biomed Inform. 79:147-148. DOI: 10.1016/j.jbi.2018.02.007

20.Zerem, E.; Kunosić, S. (2018) The ranking of scientists: Computational calculation of Z-score. J. Biomed. Inform. 81: 133-134. DOI: 10.1016/j.jbi.2018.04.002.

21. Zerem, E., Kunosić, S., Imširović, B., \& Kurtčehajić, A. (2021). Science metrics systems and academic promotion: bosnian reality. Psychiatria Danubina, 33(suppl 3), 136-142. 